
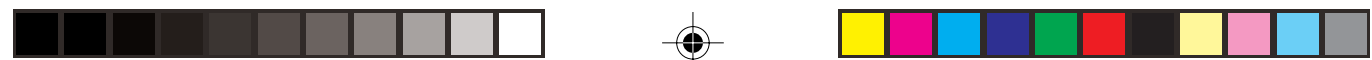

\title{
4. Politics, democracy and the media: Case studies in Fiji, Tonga and the Solomon Islands
} \begin{abstract}
This article looks at three South Pacific Island nations-Fiji, Tonga and the Solomon Islands - in terms of some landmark changes occurring in their political arenas. Fiji, beset by racial and political problems culminating in three coups, is experimenting with a multiracial, multiparty cabinet that could be emulated by other multiethnic countries. Tonga, a Polynesian monarchy, has recently seen an unprecedented number of protest marches against the ruling elite, the death of its King, and is in experiencing palpable democratic changes. In the Solomons, the strong desire for a fairer political system was manifested in the 2006 riots in Honiara. It caught the Regional Assistance Mission to the Solomon Islands (RAMSI) napping and brought into question the sufficiency and focus of Australia's intervention policy in the country. The media has been a key player in these events. Regularly accused of adding fuel to fire in its coverage of crises, the media faces constant government pressure in all three countries. This article argues that rather than the media, the sources of discontent and instability are self-serving leaders clinging to outdated political systems. The authors believe political reform, not media control, is needed.
\end{abstract}

SHAILENDRA SINGH and SOM PRAKASH

University of the South Pacific, Suva, Fiji

I

N RECENT years, both Fiji and the Solomon Islands have experienced ethnic conflicts culminating in coups and the forcible removal of demo cratically elected governments. In Tonga, a homogeneous but hierarchical society, the conflict is along class lines. The King and his nobles have a 

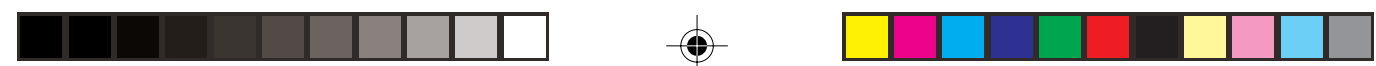

\title{
ECO-JOURNALISM AND SECURITY
}

monopoly on political power and lord it over the rest of the population. Fiji is now attempting to forge a new political path based on power sharing between the two major ethnic communities. Fiji's rugby sevens kingpin, Waisale Serevi, spoke for many in June 2006 after Fiji won its maiden International Rugby Board Sevens series title. In a brief, but telling, overflow of spontaneous emotion, Serevi told an international television audience:

\begin{abstract}
We would like to say thank you very much to the people back home for supporting us, for the prayers; even though everyone is not here, but we can feel that your prayers and support is with us. We've have just elected our new government in Fiji. Things are alright in Fiji. If you people are watching or listening, you have to come to Fiji-that is the way the world should be...
\end{abstract}

Fiji Prime Minister Laisenia Qarase expressed deep gratitude for those words: 'Yes, we have a new government that offers fresh hope and promise. Yes, things are alright with us.' With the May 2006 General Elections returning Qarase's ruling Soqosoqo Duavata ni Lewenivanua (SDL) Party to power, and with the multiparty cabinet recommended by the 1997 Constitution in place, many people both within and outside Fiji feel optimistic about Fiji's political future.

Meanwhile, the pro-democracy protests that rocked Nepal in April and forced King Gyanendra to restore Parliament was a major international news event that in the internet and satellite TV age would have been witnessed half a world away in the tiny South Sea island Kingdom of Tonga. The upheaval would have been cause for contemplation for all Tongans. The Polynesian monarchy is also in the throes of a popular democracy movement. A blatant attempt to silence the biweekly Taimi o' Tonga newspaper in 2003 through legislation backfired when an estimated 6000 protestors turned out for what became the biggest march in the nation's recent history. Tonga has since seen even bigger demonstrations, signaling that it could be on the cusp of its first major political change in 150 years in the wake of the King's death.

In the restive Solomon Islands, people, apparently fed up with a political system that has seen a constant change of governments and which has bred corruption, took matters into their own hands when they went on a rampage in the capital, causing damage worth millions of dollars. The riots exposed what observers say are weaknesses in Australia's intervention in the country,

68 PACIFIC JOURNALISM REVIEW 12 (2) 2006 

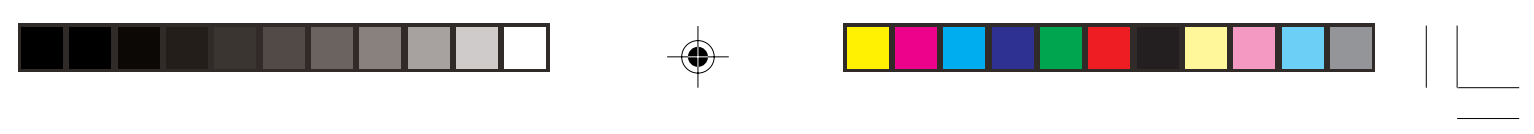

ECO-JOURNALISM AND SECURITY

and drew attention to the need for a rethink and redirection of the policy. While the Regional Assistance Mission (RAMSI), which commenced in July 2003, brought an end to the fighting between different ethnic groups, some of the underlying causes of the conflict continue to fester.

\section{Fiji: A political experiment}

In Fiji, the sense of optimism that has resulted from the successful formation of a multiparty cabinet has not been a regular feature of Fiji's recent history. After three coups, Fiji has not always been the paradise many people wish it to be. Pope John Paul II's wishful words: 'Fiji - the way the world should be' took on a heavy ironic meaning after the two coups in 1987 and then again in 2000.

A multiethnic nation of more than 850,000 people made up of indigenous Fijians and Indo-Fijians (descendents of 60,000 indentured labourers), Europeans, part-Europeans and others of mixed descent (officially referred to as the General Electors), Fiji was a British Crown colony for 96 years before independence in 1970. This was achieved in a smooth, orderly manner without the prolonged period of nationalist struggles often associated with Asian and African countries. As historian Professor Brij Lal says, the 'consensus' Constitution of independent Fiji did not make any radical departure from the colonial past; in fact, it 'entrenched the same principles that had governed Fiji's colonial politics' (Lal, 1986, p. 75). The three ethnic groups were seen as the balancing legs of a 'three-legged stool'. Fijians owned and provided the land, the Indo-Fijians provided cheap labour, and Europeans contributed skilled manpower and capital. In actual practice, the three groups did not enjoy equal status, privileges or access to power. Through this so-called balancing exercise, the following three principles were entrenched in the Constitution of independent Fiji: the paramountcy of Fijian interests, the protection of European privilege and the Indian demand for parity in political representation.

Elections to the House of Representatives (the Lower House) were based on the principle of racial representation. While the parity of representation was recognised with respect to Indians and Fijians, each having 42.3 percent of the seats, the General Electors were given a disproportionate 15 percent of the seats with only 4 percent of the national population.

This was supposed to be an 'interim solution' lasting only for the first House of Representatives elected after independence in 1972. It is interesting PACIFIC JOURNALISM REVIEW 12 (2) 200669 

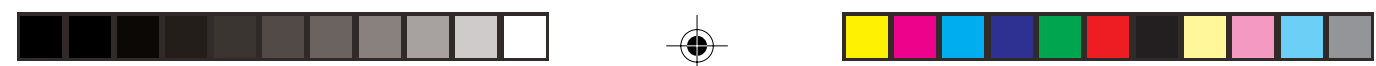

\section{ECO-JOURNALISM AND SECURITY}

that in the 1987 elections, the manifesto of the Labour Party led by Dr Bavadra said: 'Our aim is the creation of true democracy in this country and to put an end to the many undemocratic features that dominate the political life of Fiji' (see Lal, 1986, pp. 148-55). Fiji's fifth General Election since Independence, in 1987, caught almost everyone by surprise.

For the first time, the politics of 'race' was being openly challenged by the politics of 'class', and the philosophy of 'democratic socialism' was being pitted against Fiji's long legacy of 'communalism' enshrined in the Constitution. (Lal, 1998, p. 38)

But the National Federation-Fiji Labour Party government was cut short by military strongman, Sitiveni Rabuka's coup in May of that year. Many losing politicians welcomed Rabuka's coup when it happened. In the first press conference after taking over power, Rabuka candidly admitted he had been in touch with a number of Alliance politicians before and during the elections. In short, as Lal suggests, 'the Fiji coups were the culmination of a convergence of various wounded egos and aggrieved interests' (1988, p. 58). Lal goes on to claim that the 'most popular and also misleading view' of the 1987 Fiji coup is that 'it was simply the culmination of a long festering racial conflict between Fijians and Indians' (1988, p. 65). To explain conflicts in mere racial terms is among the easiest of options for ill-informed fly-by-night overseas journalists or facile local writers; and there were others also who found it convenient, for one reason or another, to believe in such a myth and thus perpetuated this misleading view.

Up until this momentous occasion, the press in Fiji was allowed to do more or less what it wanted. But with the coup, Rabuka accused the critics of the regime of spreading misinformation to 'arouse world opinion against those in control in Fiji'. Strict self-imposed censorship was to be used-even with overseas opinions. How sensitive Rabuka's regime had become regarding any criticism may be judged by its reaction to an academic review of Rabuka's first book, No Other Way. The reviewer, an academic from the University of the South Pacific and one of the co-authors of this article, was incarcerated in the Army barracks and subsequently placed under house arrest - without trial (see 'Review: Return to Theatrics', in Prasad, 1988, pp. 100-104).

In July 1990, a pro-indigenous Constitution endorsed by the chiefs, was promulgated by the President. Rabuka rationalised the need for Fijian para- 

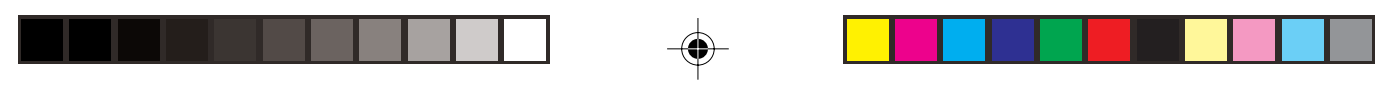

\section{ECO-JOURNALISM AND SECURITY}

mountcy and claimed that the new Constitution enshrined the major aims of his 1987 coups. If Rabuka was responsible for this controversial Constitution, he was also responsible for the 1997 Constitution.

\section{A defensive media}

In May 1999, Fiji went to the polls under the new Constitution, producing a historic result. The People's Coalition won the elections and for the first time Fiji had an Indian Prime Minister in the shape of Mahendra Chaudhry. It was in power for a year when it was ousted in a coup by George Speight. For the year the People's Coalition government was in power, it received mixed reactions. The government began to view the media as insensitive, arrogant and siding with its opponents. In response, the media saw the government's attack as a strategy to divert attention away from the problems it was facing (Fiji Times, 16 August 1999; see also Norton's incisive analysis of the 1999 Fiji elections).

The People's Coalition had won 58 out of the total of 71 seats in the Lower House. Chaudhry's Labour Party had won 37 seats in its own right. So in purely democratic terms, there was no question about the legitimacy of the governing party. But in Fiji, where there are two different ethnic groups in almost equal numbers, and where voting is based on race, the situation is more complicated - especially when rebels like Speight have access to guns and a dubious nationalistic 'cause' to parade before gullible and/or opportunistic supporters. Speight ousted the Chaudhry government on its first anniversary, 19 May 2000.

Once the coup was effected, Speight managed to exploit the media rather cleverly to spread his message of hate and rally support for his indigenous 'cause'. The media could not resist quotes like: 'We do not look the same, we do not eat the same food, we do not smell the same', in referring to ethnic Fijians and Indians. For a while even the more seasoned overseas correspondents were taken in by his clever words and stances.

It took almost two months to free the hostages, through a difficult and prolonged negotiation. A civilian caretaker government was appointed by the military until the elections in 2001. These elections were won narrowly by the Qarase-led SDL Party. Hopes for a multiparty cabinet, as mandated by the Constitution, were dashed when talks ended over the Prime Minister's allocations of token portfolios to the second largest party, the Labour Party.

It took another five years and a second general election for the multi- 

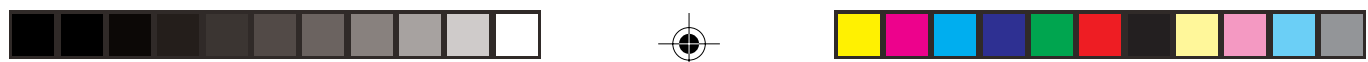

\section{ECO-JOURNALISM AND SECURITY}

party cabinet to become a reality. Laisenia Qarase won the 2006 elections with an increased majority, and therefore perhaps with a greater sense of security, offered Labour Party ministers significant cabinet seats. Qarase, like Rabuka earlier, seems to have come of age. While the multiparty concept is not without its problems, many people on both sides of the racial divide see it as a much better option than the adversarial politics that pitted one race against another in Parliament. Fiji's vibrant media, criticised for its coverage of politics in the past, is playing a key role in fostering an air of hope and optimism. Both the letters to editors in newspapers as well as the editorials have been urging the powers that be to make the multiparty concept work.

Some evidence that the population has warmed to the message can be seen in the surge in Qarase's approval rating in a recent The Fiji Times Tebbutt Poll (Fiji Times, July 2006). One thousand and twenty eight adults were questioned in six districts between July 28-31. Qarase, who is seen to be championing the multiparty concept, scored a 73 percent approval rating for his performance as prime minister. This was higher than that achieved by any other prime minister since 1992. While Qarase's approval rating was highest among ethnic Fijians (92 percent), he also enjoyed a high rating of 80 percent among other races. Indo-Fijians were much lower in their rating but even so, more than half (53 percent) approved of his performance.

On the other hand, Fiji Labour Party leader Mahendra Chaudhry's approval rating declined to 36 percent following drops in support from ethnic Fijians and other races. Chaudhry's party has been experiencing a serious rift, and he has been accused by opponents of attempting to derail the multiparty cabinet, a charge he strenuously denies. His approval rating among IndoFijians remains high at 59 percent, showing just a small decline of five percentage points from 64 percent in June 2006.

Fiji's population appears to favour the multiparty cabinet and, should it survive, Fiji could be at the dawn of a new political era. At least for the moment it can be said with some hope: Fiji-the way the world should be!

\section{Tonga: People's power}

Tonga's normally staid capital, Nuku'alofa, was the scene for some unsettling events in August and September 2005 when about 10,000 people protested in support of striking civil servants who wanted the government to reconsider huge disparities in salary increases between junior and senior staff. 
What began as a protest by 4000 civil servants for fair treatment became a rallying cry for democracy, with the crowd waving banners declaring, 'The people want a new government of the people, by the people, for the people', 'Let freedom rule' and 'The Kingdom is ours' ('Tongan protest marchers call for political reform', 2006). Prior to this, protests had been rare and the last of any significance was in 1991 when 1500 people marched against the sale of Tongan citizenship to non-Tongans ('Thousands march on Tongan Parliament', 2003). Around 10 percent of the population had turned out for each of the two big marches.

The current mood in Tonga seems to favour major constitutional changes. The people no longer want a system under which they are unable to directly choose their government and under which corruption and patronage seem to thrive. While Tonga's octogenarian monarch, King Taufa'ahau Tupou IV who died on 10 September 2006, was said to be popular, the royal children are perceived to have used their privileged positions to take over national assets, and have not endeared themselves to the people. The target of the marchers' anger, they faced demands for the return of assets such as power generation, Tonga's orbital slots, and the internet domain address .to.

Tonga's executive branch includes the Prime Minister and 14 cabinet members. The King appoints ten cabinet members for life. The unicameral Legislative Assembly is controlled by the royal and noble families. It consists of nine nobles who are elected by the 33 hereditary nobles of Tonga. The adult voting population elects the nine people's representatives. The Constitution, often described as a mixture of Tongan, Christian and Western values, has undergone only minor changes in the 131 years it has been in existence.

The government probably averted a serious crisis when it caved in to the strikers' demands for salary increases of between $60-80$ per cent along with promises of political reform. Before the settlement, the protest appeared to be getting out of hand, with four government-owned vehicles set alight and students threatening to burn the government buildings. Such open displays of hostility towards the monarchy were unprecedented. The few lone voices of the Tongan democracy movement of the 1970s had become a deafening crescendo which the establishment could no longer ignore, as acknowledged by the Princess Regent, Salote Mafile'o Pilolevu, in her address to Parliament on 1 June 2006: 

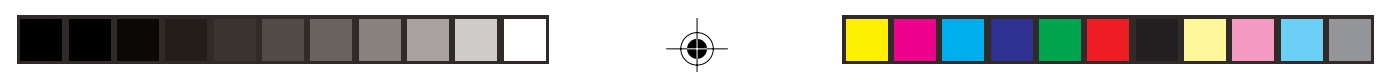

\section{ECO-JOURNALISM AND SECURITY}

Change is a fact of life, and thus political changes or reforms are inevitable [and] must be discussed thoroughly by both the public and the government (Tonga must avoid political disaster, 2006).

\section{Landmark changes}

Inundated with protests, petitions and the looming threat of violence, the King made some landmark political concessions. He appointed the kingdom's first full-time commoner Prime Minister, Dr Fred Sevele. The country's first official political party, the People's Democratic Party (PDP), was allowed to register as an incorporated society. Cabinet, which had been the domain of nobles, saw two ministers appointed from the nine elected people's representatives. Another sign of the changes sweeping across Tonga's political landscape was the formation of the National Committee on Political Reform in October last year to hold consultations with local and overseas Tongans. The mood for change became clear once the committee began sitting. At one meeting the King's nephew, Prince Tu'ipelehake, a committee member, was told by a man that, 'we should do away with the King's table (Cabinet Ministers) and your table (Noble's Representatives)' ('Political reform committee continues its mission', 2006). The Prince, who supported the reforms, died in a car collision in the US in July 2006. At the University of the South Pacific in Suva, Fiji, Tongan students called for an increase in the number of seats for commoners (Tongan students back political reforms, 2006).

Auckland University anthropologist Dr 'Okusitino Mâhina believes that reforms were overdue. Mâhina (2004) says King Tupou I's accession to the throne in 1854 brought relief to commoners from the 'political bondage systematically administered by the divinely-sanctioned Tu'i Tonga and the oppressively powerful Kanokupolu chiefs'. King Tupou I also unified the nation, gave it a constitution and an administrative system, putting an end to 50 years of internal wars. His successor, King George Tupou II (1893-1918), made Tonga a British protectorate in 1900 until complete independence on 4 June 1970 (Encyclopedia-Tonga, 2005). But, Mâhina adds, while the 1875 Constitution was truly ahead of its time, especially in accommodating many of the basic tenets of Western democracy, it has largely outgrown much of its cultural and historical relevance over time. While some aspects of the Constitution duly deserve preservation, many others demand serious revision (Mahina, 2004).

While the King had not given up any of his powers, the concessions he

74 PACIFIC JOURNALISM REVIEW 12 (2) 2006 

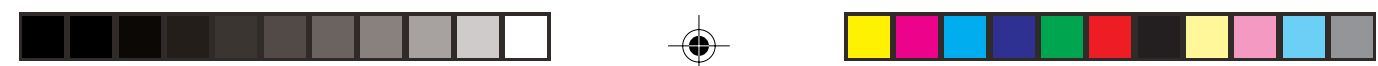

ECO-JOURNALISM AND SECURITY

granted are historic and significant, and could turn out to be the thin edge of the wedge. The Nepal experience shows that once people have tasted freedom, they will not only agitate for more, but also resist any moves to roll them back.

\section{Tongan media}

The Tongan government has a heavy presence in the print and broadcast media. It owns one of the three newspapers and runs the national television and radio station. The state-owned media and website tend to tow the government line. Private-owned broadcast media, until recently, mostly aired foreign programmes, music and news. Robie (2003a) says that some Pacific Island governments, while claiming to be democratic, tend to behave rather autocratically towards the media:

\footnotetext{
Politicians frequently speak out on how the media ought to be 'responsible', ie. either self-censor to the benefit of the government of the day, or propagandise on its behalf. Normal independent reporting and questioning by the media is often seen by some politicians as tantamount to subversion. Thus politicians are often tempted to impose gagging or licensing laws (Robie, 2003a).
}

A leading critic of the Tongan establishment, newspaper publisher Kalafi Moala, has been at the receiving end of such gagging attempts. Moala set up Tonga's leading biweekly newspaper, Taimi 'o Tonga, in 1989. Police frequently raided the newspaper's Tongan offices and staff received threatening phone calls. In 1996, Moala was jailed for 26 days for contempt of Parliament but released when the Supreme Court found he had been wrongfully imprisoned. In February 2003, the government seemed to have reached the end of its tether and banned the importation of the biweekly, alleging that it was 'foreign,' had a 'political agenda' and put up with 'unacceptable journalistic standards'. The government went to the extraordinary length of amending the Constitution and passing legislation to keep the newspaper out, but in both cases, the Supreme Court overthrew the amendments.

The Taimi o' Tonga newspaper practises what could be described as 'radical journalism'. This is journalism that seeks to bring about change, overcome exploitation, corruption and human rights violations, or to improve the living conditions of ordinary people in order to achieve just societies. Such 

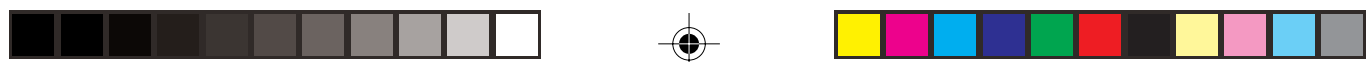

\section{ECO-JOURNALISM AND SECURITY}

journalism does more than passively report news events or interpret them-it attempts to expose destructive or oppressive situations and to help 'clean them up' (Robie, 2006, p. 9).

The Tongan ruling elite sees this form of journalism as confrontational, disrespectful, and alien to Pacific culture. But ordinary Tongans think otherwise. The Tongan government's efforts to silence the Taimi o' Tonga through legislation resulted in Tonga's first major protest march and then gathered momentum from then on. In hindsight, the move against the newspaper was probably one of the government's most serious miscalculations.

\section{The internet and democracy}

The internet, with its unique qualities, has invigorated national debate in Tonga. According to the Internet World Stats website, Tonga had 3000 registered users at November 2005. The internet has had the greatest impact on overseas Tongans by making news available to them virtually instantaneously. It is very different from when overseas Tongans, who number more than 100,000, received the newspaper long after the news had become stale. The reach of the internet, in Tonga's case, is remarkable. While the Taimi 'o Tonga, has a circulation of 9000, Tonga's leading news portal, Matangi Tonga Online, had more than 43 million hits for the year ending 31 May 2006 (Matangi Tonga Online Advertising Statistics, 2006). Unencumbered by space restrictions, the internet allows Tongans a greater say in national affairs than newspapers. Between May 2 and June 6 in 2006, Matangi Tonga Online published 26 letters from overseas Tongans. All but three were commentaries on governance, the royal family or politics. They ranged from a few paragraphs to an extended response to Princess Pilolevu's speech in Parliament on June 1.

A letter entitled, 'Commoners need to become leaders not followers,' by Ms Tupou Layton (2006) was typical of some of the sentiments expressed. She wrote that change would be difficult because Tongans were easily persuaded to be followers, and that in order to get out of poverty, commoners needed to stop 'fearing' the royals. She accused the royals of taking all the wealth in Tonga and only picking their relatives and friends for jobs. Tama Foua (2006), writing from the United States, lamented about rising taxes, saying the accepted government wisdom seemed to be that workers should be 'more cooperative, work harder, take pay cuts, pension cuts, benefit cuts, and smile'. 
Whether overseas Tongans should have a say in national affairs has been a matter of national debate. Remittances from overseas Tongans account for more than 30 percent of Tonga's GDP, making Tongans one of the heaviest recipients of remittances (World Bank Global Economic Prospect report, 2006). Overseas Tongans financially supported the civil servants strike, which helped sustain it for six weeks. Through the internet, they are able to monitor on a daily basis events in the country and take part in national discourse. In short, overseas Tongans are already significantly involved in national affairs. It would be virtually impossible to stop them, particularly with the communication revolution brought about by the internet.

\section{The Solomon Islands: The Honiara riots}

A United Nations Development Fund for Women (UNIFEM) 'early warning report' monitoring levels of peace and conflict in the Solomon Islands from August to December 2005 had warned of the country's vulnerability to renewed conflict. While acknowledging the gains made by the Regional Assistance Mission to the Solomon Islands (RAMSI), it said that some of the underlying causes of the conflict remained unresolved. In the context of the 2006 elections, the report predicted that while the Solomon Islands stood at a point of great potential to move forward, there was also the potential for renewed conflict (Monitoring Peace and Conflict in the Solomon Islands: Gendered Early Warning Report No. 2, 2005, p. 1).

Four months after the report was released, the Solomon Islands faced further upheaval. Rioting that shook Honiara in April following the announcement of controversial politician Snyder Rini's appointment as Prime Minister caught RAMSI unawares. The force, made up of soldiers and police from Pacific Island countries under the command of Australia, was a partial success in that it stopped the ethnic war between Malaitans and the people from Guadalcanal. Also, 3400 weapons were surrendered and 600 arrests made and 1000 charges laid in the first five months of the operation (RAMSI and the strife in the Solomons, 2006).

But in its fervent pursuit of politicians and militants charged with offences during the civil unrest, RAMSI overlooked, or at least underestimated, the level of discontent among the general population. Many of those who rioted were ordinary people fed up with the state of affairs in the country, particularly the behaviour of their political and business leaders. 

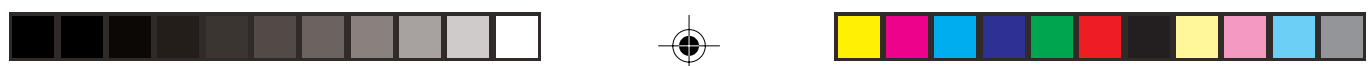

\section{ECO-JOURNALISM AND SECURITY}

The UNIFEM report identified indicators presenting a high risk of conflict as follows:

- Corruption in government

- Women's lack of participation in government processes

- Dissatisfaction with provision of government services

- Inability to participate in government decision-making

- Lack of trust between political groups

- Frequency of disputes concerning land

- Women's lack of involvement in community resolution of land disputes

- Economic inequality within the population

- Social and ethnic relations

Of all indicators in the study, corruption in government recorded the highest risk score. Corruption often features among the issues which trigger conflict, the report emphasised. It also pointed to a 'pervasive sense of exclusion from government processes and decision-making', indicating a 'lack of linkages and engagement between government and its citizens. Dissatisfaction with the provision of government services is high, it said (Monitoring Peace and Conflict in the Solomon Islands: Gendered Early Warning Report No. 2, 2005, pp. 4-6).

The pent-up fury that was manifested in the violence in April was, as alluded to by the UNIFEM report, caused by years of political instability (fostered, for example, by corrupt politicians) that almost ruined the economy, causing a decline in living standards. Local resentment against some wealthy Chinese businessmen who are buying up property in the Solomons (and are suspected of funding corrupt politicians) has been used to explain the riots. Rini's appointment was said to have triggered the violence as he was perceived to be one of the beneficiaries of the Chinese largesse. If anything, the riots raised questions about the effectiveness of RAMSI.

Hameiri (2006) believes RAMSI was only a temporary respite. It was successful when it came to disarming and prosecuting former militants and thugs but much less so when it came to putting in motion governance reforms:

From the outset, Australian policymakers have identified poor governance as the root cause of conflict in the islands. Therefore, the promo-

78 PACIFIC JOURNALISM REVIEW 12 (2) 2006 

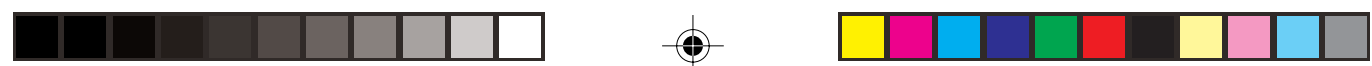

ECO-JOURNALISM AND SECURITY

tion of good governance was seen as the key to sustainable economic development as well as to long-term peace building. (Hameiri, 2006)

University of Hawaii academic Tarcisius Kabutaulaka (2006a) says there are many lessons that Australia (and the rest of the RAMSI participating countries) need to learn, not only from the April 18 riots, but also from previous years of operation in the Solomon Islands. Kabutaulaka defines the Australian approach as centering on (a) accelerating economic growth, and (b) fostering a functioning and effective state. While both are worthwhile issues to be addressed in post-conflict situations, the Australian approach conceptualises economic growth in an aggregate manner. This means that economic disparity and its social consequences are of little concern with the assumption that increases in GDP will trickle down, providing opportunities for all. Past experiences, both in the Pacific Islands and elsewhere, have demonstrated that this is rarely, if ever, the case. Related to this is the push to build institutions for market-led development. This is wrapped up in language (along with it ideologies) such as 'good governance' and 'strengthening institutions,' and are promoted as a way of addressing the 'problems' of 'weak state', 'failing state' etc. Kabutaulaka believes this approach is flawed:

Building and strengthening state institutions is in itself not a bad thing. However, it becomes problematic when it assumes that institutions should be built in a particular way, or (should be a) particular kind of institution. In this case it should be an institution that reflects neoliberal values that work in Australia and other developed countries. There is often no questioning whether or not they will work in the Solomons or East Timor. In the case of the Solomons, Australia refuses to support (and indeed proactively opposes) a proposal for federalism, which had been discussed even before independence. Australia wants to build institutions of government that work in Canberra and expect them to work equally well in the Solomons. (Kabutaulaka, personal communication, 2006)

According to Kabutaulaka (2006b), the rioters reacted to what they perceived was a 'corruption of the democratic process, in particular, concerns about the process of selecting a prime minister, and how "business interests" allegedly influenced the formation of governments'. He questions how, against the desire of many Solomon Islanders, Rini managed to win the contest for the

PACIFIC JOURNALISM REVIEW 12 (2) 200679 

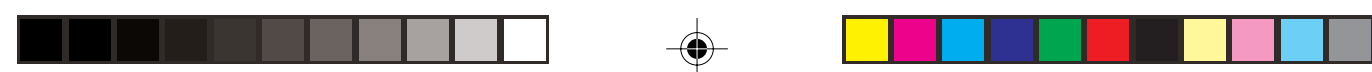

\title{
ECO-JOURNALISM AND SECURITY
}

Prime Minister and bring back into power the 'old guard'. He also points to the weakness of party systems, the fluidity of political alliances, and the process of selecting a prime minister:

In the absence of a strong party system, voters tend to vote for individuals rather than political parties. These individuals, after being elected into Parliament, form political alliances and then compete to capture the prime minister position and subsequently form government. (Kabutaulaka, 2006b)

Most Solomon Islanders have no control over such maneuvering and become spectators in a process that assumes that their respective Members of Parliament have their interest at heart. Past experiences have shown, however, that in many cases, the constituents did not usually influence the choice of Prime Minister and the political alliances that were formed. Rather, there have been allegations that powerful businessmen - mostly Chinese - pay large sums of money to Members of Parliament in order to ensure that any government that was formed served their interests.

Kabutaulaka suggests the Solomon Islands could learn from nearby countries Fiji and Papua New Guinea, which have adopted regulations to prevent 'party hopping'. Unless similar changes occur, getting into Parliament, selecting a prime minister, forming governments, and acting in the national interest will continue to be a tricky business in the Solomon Islands. In light of the riots, Kabutaulaka recommends a review of the nature of the 'partnership' between Solomon Islands and Australia:

\begin{abstract}
At the moment, the partnership is dictated by, 'Australia says, Solomon Islands does'. Australia must learn to genuinely listen. They often say that Solomon Islanders are not talking, not expressing themselves. How could Solomon Islanders talk and express themselves when Australia never stops talking, or does not sit quietly and listen for a change? (Kabutaulaka, 2006b)
\end{abstract}

\section{The role of the media}

A veteran Solomon Islands journalist chose the 2006 World Media Freedom Day to criticise his own profession, saying the country's media did little to impede the crime and corruption that took root during the civil crisis. Johnson Honimae said the Solomon Islands experienced social unrest because the media 

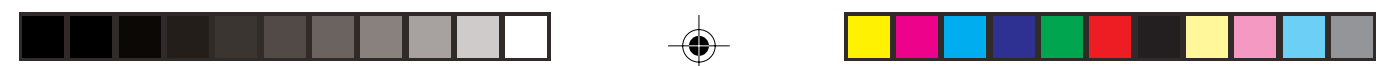

ECO-JOURNALISM AND SECURITY

had not played its role as a watchdog on the leadership of the country since independence. He also observed that the country's resources were virtually stolen because the media did not speak out (Media rapped for weak role, 2006). But in 2002, a report by the New York-based Committee to Protect Journalists said that 'despite a hostile political and economic atmosphere, the Solomon Islands' small but tenacious media managed to pursue controversial stories, including exposés of official misconduct and links between the government and ethnic militias' (Committee to Protect Journalists, 2002). Johnson's frustrations probably have more to do with the lack of change in the Solomon Islands despite the various scandals exposed by the media. Robie (2005) aptly sums up the challenge that poorly-paid and trained Pacific Island journalists faced as the region was plunged into turbulent times with the decade-long civil war on Bougainville, the Fiji coups, ethnic conflict in the Solomon Islands, factional feuding in Vanuatu and political assassinations in New Caledonia and Samoa:

At times, it takes raw courage to be a neophyte journalist (and) Pacific journalists continue tackling the political and cultural perils of their craft with guts and gusto. (Robie, 2005)

Since 2004, the media has been able to operate in a less-oppressive environment as RAMSI's presence improved security for local journalists. Some militia leaders who had threatened the press were put behind bars. In his book Mekim News (2004), Robie stresses the need for training and education to adequately equip Pacific Island journalists to effectively fulfil their roles:

Education for journalists and a professional ethos are a vital part of empowering the public in a democracy. Educated journalists are more likely to offer fresh and sustainable solutions. (Robie, 2004, p. 250)

The UNIFEM report also recommends capacity building for journalists to enable the media to better understand gender issues. A media scan of the Solomon Star carried out between 15 June and 25 November 2005 by UNIFEM showed a strong bias against the representation of women. Also, in its analysis of 1681 articles on peace and conflict issues, the report found slightly more articles concerning peace than concerning conflict. Of the articles concerning conflict, the most common topics were unrest and political and legal

PACIFIC JOURNALISM REVIEW 12 (2) 200681 

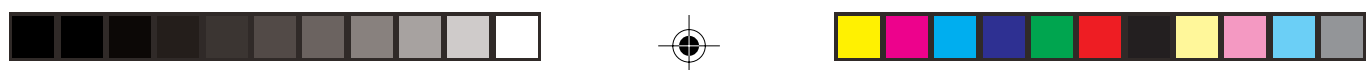

\section{ECO-JOURNALISM AND SECURITY}

issues (both 36 percent), followed by crime ( 24 percent). Of the items about peace, peace-building activities was the most frequent topic (53 percent), followed by political and legal issues (39 percent) and community development (32 percent). Only eight percent of articles about peace and /or conflict had a focus on women. The report said the results suggested a need to encourage and provide training for women's organisations so that they could submit more press releases to enable those working in the media to better understand issues of gender representation.

\section{Conclusion}

To conclude, we have argued that political systems in the three countries discussed have passed their use-by-dates and are a security threat, particularly in the Solomons and Tonga. The situation is compounded by self-serving leaders bent on clinging to these political systems. Their stand often goes against the call from the grassroots. The resultant tension was manifested in the uprisings seen in these two countries recently. With the death of King Taufa'ahau Tupou IV, Tongans are waiting to see in which direction his son and successor, King Siaosi Tupou V, will take the country. Ratuva (2006) believes two decisive issues - allowing for greater democratisation and declaring all business interests - are at the heart of his fate. If he fails to live up to the 'tsunamis of reformist expectations, [events] may turn out to be a Shakespearian tragedy of kingly proportions'. The new King, apparently aware if this reality, has already declared that he will sell his interests in the national power company, brewery, a telecommunications company and an airline. In Fiji, the people want to move away from racial politics. Fiji's Prime Minister Qarase, who seems to be heeding this call, has seen an improvement in his approval ratings. The media in all three countries are playing a key role in these developments. The claim that the media is a security threat is made mostly by leaders who fear change and the accompanying loss of privileges. Appreciation of the media by the masses was seen in Tonga when government efforts to silence the Taimi o' Tonga in 2003 was met by the biggest protest march in the country's history. In the Solomon Islands, the media has over the years exposed government misdeeds. When this failed to bring about change, the people took matters into their own hands. In the midst of these tumultuous changes, powerful nations in the region such as Australia need to get proper assessments of the situation on the ground rather than rush in with short-term, ill-conceived and narrowly focused interventionist policies that 82 PACIFIC JOURNALISM REVIEW 12 (2) 2006 
tend to be short-lived. The Australian government, through RAMSI, has been mostly dealing with the outcomes of the conflict. The Honiara riots reflect the need to focus on the underlying causes with as much zeal if an enduring solution is to be found. The Fiji experience has so far shown that bold steps such as the trying out of a multiparty cabinet can lead to some positive outcomes for the majority of the people.

\section{References}

Alley, R. (1986). The emergence of party politics. In Lal, B. (Ed). Politics in Fiji. (pp. 28-48). North Sydney: Allen \& Unwin.

Bain, K. (1989). Treason at 10: Fiji at the crossroads. London: Hodder and Stoughton. Braddock, J. (2005). Public servants' strike deepens Tonga's political crisis. World Socialist website. (Retrieved May 2006) www.wsws.org/articles/2005/aug2005/tong-a19.shtml

Committee to Protect Journalists (2002). Attacks on Press, 2002. (Retrieved June 2006).

www.cpj.org/attacks02/asia02/asia.html

Commoners need to become leaders not followers. (2006, April 19). Matangi Tonga Online. (Retrieved June 2006). www.matangitonga.to/article/letterscomments/ povertyhardship/layton190405.shtml

Country Reports on Human Rights Practices. (2005). US Department of State. (Retrieved June 2006). www.state.gov/g/drl/rls/hrrpt/2005/61629.htm

Deryck, S. (1988). Politics of illusion: the military coups in Fiji. New South Wales: New South Wales University Press.

Encyclopedia-Tonga. (2006). infoplease. (Retrieved May 2006). www.infoplease.com/ce6/world/A0861590.html.

Hameri, S. (2006, April 24). What really went wrong in the Solomons? theage.com.au (Retrieved June 2006). www.theage.com.au/articles/2006/04/23/ 1145730805256.html

Kabutaulaka T. (2006). Seeking answers in the ashes of Honiara. (2006, April 20). East West Centre. (Retrieved June 2006). www.eastwestcenter.org/events-endetail.asp?news ID $=318$

Lal, B. (Ed.). (2000). Fiji before the storm: elections and the politics of development. Canberra: Australian National University, Asia Pacific Press.

Lal, B. (Ed.). (1986). Politics in Fiji: studies in contemporary history. Sydney: Allen \& Unwin.

Lal, B. (1988). Power and prejudice: the making of the Fiji crisis. Wellington: Victoria University.

Lal, V. (1990). Fiji: coups in paradise: race, politics and military intervention. London and New Delhi. Zed Books.

Mâhina, 'O. (2004). Emancipation in Tonga: yesterday and today. Planet Tonga. (Retrieved May 2006). www.planet-tonga.com/language_journal/ Emancipation_in_Tonga/index.shtml

PACIFIC JOURNALISM REVIEW 12 (2) 200683 

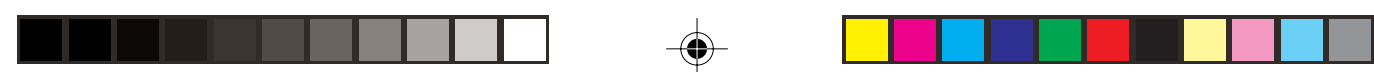

\section{ECO-JOURNALISM AND SECURITY}

Matangi Tonga Online Advertising Statistics. (2006, June). Matangi Tonga Online. (Retrieved June 2006) www.matangitonga.to/home/ads/mt-advertise/mt.shtml

Media rapped for weak role. (2005, May 9). Pacific Media Watch Online. (Retrieved June 2006). www.pmw.c2o.org/2005/sol4725.html

Monitoring Peace and Conflict in the Solomon Islands: Gendered Early Warning Report No. 2. (2005, December)

Norton, R. (2000). Understanding the results of the 1999 Fiji elections. In Lal, B. (Ed). Fiji before the storm: elections and the politics of development. Canberra: Asia Pacific Press, Australian National University.

Oceania and South Pacific. (2005, September). Internet world stats. (Retrieved June 2006). www.internetworldstats.com/list $4 . h$ tm

Political reform committee continues its mission. (2006, May 10). (Retrieved June 2006). www.matangitonga.to/article/tonganews/parliament/tonga_ncpr100506.shtml

Prakash, S. (1988). Return to theatrics. In Prasad, S. (Ed.). Coup and crisis-Fiji: a year later (pp.100-104). North Carlton, Victoria. Arena Publications Association.

Prasad, S. (Ed.). (1988). Coup and crisis-Fiji: a year later. North Carlton, Victoria. Arena Publications Association.

Rabuka, S. (2000). The Fiji islands in transition. In Lal, B. (Ed). Fiji before the storm: elections and the politics of development. Canberra: Asia Pacific Press, Australian National University.

Ratuva, S. (2006, September 20). Death signals end of an era. The Fiji Times, p.7.

Qarase's most popular PM: Poll. (2006, August 5). The Fiji Times, p. 2.

RAMSI \& the strife in the Solomons. (2006, May 2). ALP International magazine online. (Retrieved June 2006).

http://eherald.alp.org.au/articles/0506/magopine02-01.php

Robie, D. (2006). 'Four Worlds' news values: media in transition in the South Pacific. Australian Journalism Review, 28(1): pp. 71-88.

Robie, D. (2005, March 22). The perils of South Pacific reporting. Asia Media New Daily. (Retrieved June 2006). www.asiamedia.ucla.edu/article.asp?parentid=21995

Robie, D. (2005). South Pacific notions of the fourth estate: A collision of media models, culture and values. Media Asia, 31(2): pp. 86-94.

Robie, D. (2004). Mekim nius: South Pacific media, politics and education. Suva: University of the South Pacific Book Centre.

Robie, D. (2003a). Pacific media councils and cultural values: safety valves or entrenched hegemony? Pacific Journalism Review. September, 9(1): 103-122.

Robie, D. (2003b, January 12). Press freedom in the South Pacific: Tongan lawsuit win sparks optimism. Asia-Pacific Network. (Retrieved June 2006). www.asiapac.org.fj/cafepacific/resources/aspac/pacmedia03.html

Robertson, R \& Tamanisau, A. (1988). Fiji: shattered coups. New South Wales, Australia: Pluto Press.

South Asia to receive \$32b in remittances in 2005. (2006, November 18). World Bank Global Economic Prospect Report 2006. (Retrieved, June 2006)

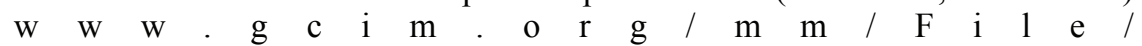

84 PACIFIC JOURNALISM REVIEW 12 (2) 2006 
ECO-JOURNALISM AND SECURITY south $\% 20$ asia $\% 20$ to $\% 20$ receive $\% 20 \$ 32$ b $\% 20$ in $\% 20$ remittances $\% 20 \mathrm{in} \% 202005$.pdf Thousands march on Tongan Parliament. (2003, October 7). nzherald.co.nz. (Retrieved May 2006). www.nzherald.co.nz/category/story.cfm?c_id=171\&objectid=3527450 Tonga: migration and the homeland. (2004, February). Migration Information Tonga. (Retrieved June 2006). www.migrationinformation.org/Profiles/display.cfm?id=198

Tonga must avoid political disaster. (2006, June 2) Matangi Tonga Online. (Retrieved June 2006). Www.matangitonga.to/article/tonganews/parliament/ tonga_regent_020606.shtml

Tonga still amazes me. (2006, April 21). Matangi Tonga Online. (Retrieved June 2006).

www.matangitonga.to/article/letterscomments/povertyhardship/tamafoa210405.shtml Tongan protest marchers call for political reform. (2006, June 1). Matangi Tonga. (Retrieved July 2006)

www.matangitonga.to/article/photonews/tonga_marchers010606.shtml

Tongan students back political reforms. (2006, June). Wansolwara, p. 5.

Tonga floats aimlessly. (2006, June 6). Matangi Tonga Online. (Retrieved June 2006).

www.matangitonga.to/article/letterscom ments/politics/ lettersionetapanimangisi060606.shtml

Shailendra Singh is the divisional head of journalism at the University of the South Pacific. He is former editor of The Review news magazine, Pacific Business and content editor of Fijilive.com and associate editor of the Daily Post. Currently consulting editor, Living in Fiji, magazine.

Dr Som Prakash is a senior lecturer with the literature division at the University of the South Pacific.

singh_sh@usp.ac.fj

prakash_s@usp.ac.fj 